\title{
The Effects of Gamification on E-learning Education: Systematic Literature Review and Conceptual Model
}

\author{
Sabri Zineb $^{1, *}$, Fakhri Youssef ${ }^{1}$, Moumen Aniss ${ }^{2}$ \\ ${ }^{1}$ Faculty of sciences, Ibn Tofail University, Kenitra, Morocco \\ ${ }^{2}$ National School of Applied Sciences, University Ibn Tofail, Kenitra, Morocco
}

\begin{abstract}
The concept of implementing games or gamification in education is becoming a growing area in the last decade and a blistering topic among researchers, professors and educational systems. Gaming in education aims to simplify and improve the learning process using technology. Nevertheless, accessibility and inclusion of gaming elements in the higher educational systems inside universities are considered yet. Most of the graduated students endure achieving the mandatory eLearning training to succeed in their integration inside companies. For example, engineers must follow some eLearning courses about Security, Ethics, Agility, Phishing Detection, General Data Protection Regulation...etc., which is tedious. Hence, our research seeks to ease and succeed the integration into companies by applying gamification to these eLearning courses to engage and motivate students to master them before graduation. This paper discusses the use of games in education, then presents a literature review about learning theories, game theory and design, game development process and tools. By collecting hundreds of papers from multiple research databases, we conceived a journal classification, a word frequency analysis using cloud visualization. Then a comparative study based on the topic's occurrences in our corpus. Finally, a comparison of different conceptual models for gamification of e-learning e nvironments. These results offer an insightful introduction to the application of game elements in educational settings and the implementation of gamification in e-learning courses.
\end{abstract}

Keywords E-Learning, Gamification, $\mathrm{S}$ erious $\mathrm{G}$ ames, $\mathrm{E}$ ducation, $\mathrm{G}$ ame-based $\mathrm{L}$ earning, $\mathrm{C}$ onceptual $\mathrm{m}$ odel, Game elements, Education

AMS 2010 subject classifications 97B40, 97C70

DOI: $10.19139 /$ soic-2310-5070-1115

\section{Introduction}

A massive amount of tools and technologies created this last decade to enhance the learning process and improve the educational systems. But how effective are the current learning tools to achieve the desired outcomes? Each interactive learning tool proved to be effective in reaching a specific result, especially games. A game can help students learn multiple training and skills required to integrate inside companies successfully. Our research aims to enhance the employment of graduated laureates in the job sector using serious games. Gamification is very effective in our case when we want to engage the learners with the content, train their reflexes or virtually simulate situations that may be difficult or expensive to reproduce in real life. It also helps reinforce information through experience.

To explore the application of serious games and gamification in education and training. We review the recent literature in our last published paper [1] by adding more than one hundred research papers to our corpus from

*Correspondence to: Sabri Zineb (Email: zineb.sabri@uit.ac.ma). Laboratory of Computer Science, Faculty of sciences, Ibn Tofaïl University, Kenitra, Morocco.

ISSN 2310-5070 (online) ISSN 2311-004X (print)

Copyright (C) 2022 International Academic Press 
new research databases as Cairn and HAL, enriching the comparative analysis too by categorizing the articles as reviews and results. With each category, we extract the approach, definition and characteristics for the review's papers; the method, the experiment and the findings for the result's articles. We analyze more than twenty articles in the comparative analysis. Then we present and discuss multiple conceptual models to reinforce our study by examining their similarities and distinctions in this paper. We structure these advancements like a section explaining the methodology we followed before detailing the corpus presentation, distribution analysis and updated statistics in the results section. Next, we conduct a comparative study based on four axes: education, gamification, e-learning and motivation-finally, a discussion section covering the analysis of multiple conceptual models of gamified elearning systems to suggest a new theoretical model at the end.

\section{Methodology}

\subsection{Literature Review}

The literature review is the first piece to carry out in our research journey and a necessary milestone to have a strong foundation or a base to reference our study. Based on analysis and synthesis, we outline that the involvement of games in education in recent years has witnessed a growing number. Following this trend, this section presents the current state-of-the-art in this field by exploring the related reviews to our research proposal: Alhammad Manal [2] in his research defined gamification then explained how it'd become one of the emerging tools used in teaching technologies. He also stated that the principal aim of applying gamification is to improve the student's engagement and knowledge. One of the evident impacts quoted in his paper is increasing their performance, improving their social skills and team collaboration. Without a doubt, this field shows excellent potential. However, his analysis concluded that this field still has gaps and faces multiple challenges, such as the lack of empirical data mentioned in his research paper. Considering gamification as one of the top trends, Oliveira Tiago [3] describe how this concept is present and becoming very important in our daily lives. In their research, they identified the essential factors in this field (Figure 1):

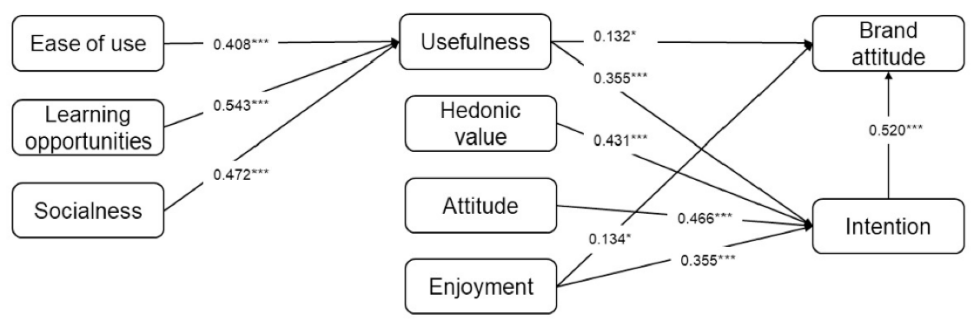

Figure 1. Theoretical model [3].

This theoretical model confirms that attitude, enjoyment, and usefulness are the most relevant predictors of intention to use gamification, influencing learning effectiveness. Games have embarked upon nearly every aspect of education. Teaching history using games is research that Laurence Hanes and Robert Stone [4] conducted to prove the impact of serious games in education by defining a model to present historical courses and information using a video game. Teaching nursing students the negotiation and improving their communication skills using games were studied using a game [5]; this pilot study's results showed promising effects as the students developed not only the technical skills but also the relational ones. Also, another research [6] found interesting effects using a serious game, developed and named "Program your robot" to teach programming. Twenty-five students played this game, and then they were evaluated to get their feedback, which was positive. They found the game very helpful in developing their solving problem skills and understanding computer programing quickly. 


\subsection{Methodology}

To establish our literature review, we choose to follow the N7+1 pedagogy[7] composed of eight steps, using Nvivo as a qualitative data analysis software to drive the analysis of our data deeply. By following every step of this process described below (Figure 2):

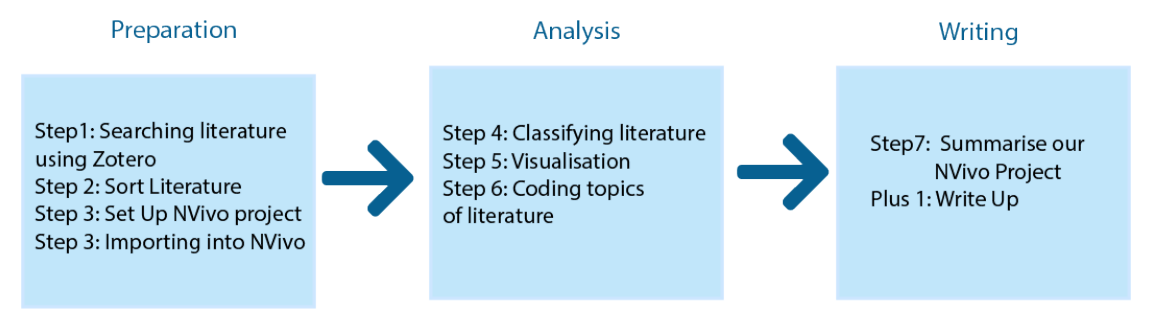

Figure 2. N7+1 approach and steps.

We built a rigorous research set by searching the literature: we used multiple databases to search for citations by title, abstract, and keyword, using the words "gamification", "eLearning", "serious games", and "training" we retrieved so many articles, we then narrowed these research papers to those related to our study, and we collected them in one RIS file using the reference management software: Zotero[8] Once we completed the corpus set and checked every research paper to ensure that the title, abstract, authors, database source, and journal are well informed for sorted literature. We imported the RIS file into Nvivo [9] which forms an important part to analyze the data collected by classifying, visualizing and coding it to get insightful findings at the end. Any fundamental corpus in its raw form is entirely unusable for analytics without significant preprocessing and compression. In the next section, we preprocessed our corpus to use it systematically and transform the research papers into a form ready for computation and modelling. We had multiple results based on every single research paper includes DOI, title, abstract, keywords, authors, and the publishing journal using the content extraction, paragraph blocking, sentence segmentation, and word tokenization [10], (Figure 3):

\section{Results}

\subsection{Corpus Presentation}

We extracted one hundred eighty-seven papers conducting researches on gamification and serious games application in education and training using "Science Direct", "Springer Link", "Web of Science", "IEEE Xplore Digital Library", and "Scopus". The papers retrieved from these research databases are distributed as the following: 45 articles from "Springer Link", 68 from "Science Direct", 41 from "Scopus" and 13 from "IEEE Xplore Digital Library", 25 papers from "HAL Archives Ouvertes" and five from "Cairn", see (Figure 4).

The distribution of the selected research papers as described in the figure 4 above, most of the documents are journal articles, and nearly $15 \%$ are conference papers.

\subsection{Corpus Distribution Analysis}

The published research papers about applying gamification in eLearning are significant. We note that the most frequent words in these papers of our corpus are: learning, games, gamification, educational, education, which reflects the focus of recent researches on this field of education and training using gamification and reveals the evident potential of this research (Figure 5). 


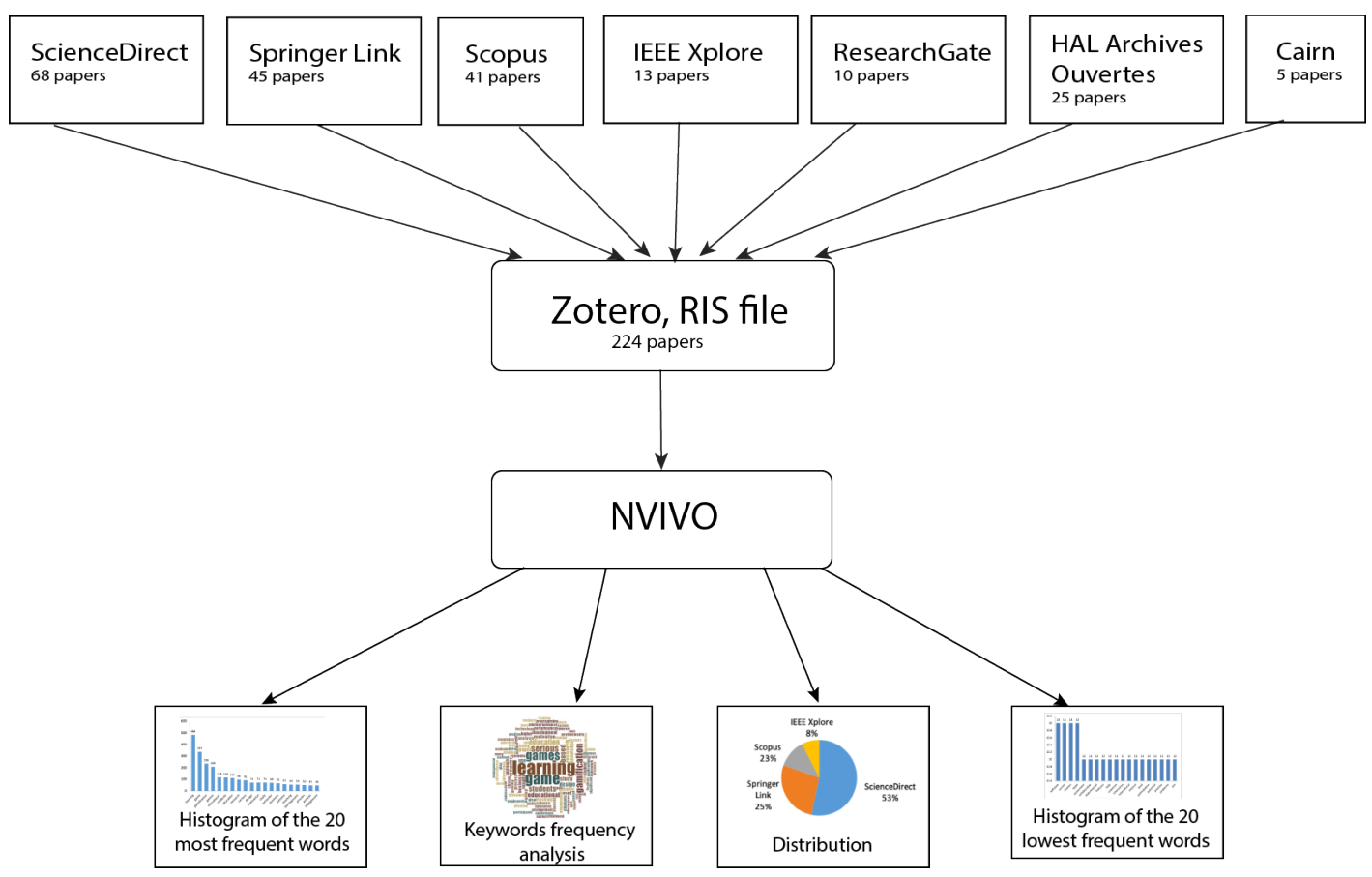

Figure 3. Illustration of the data analysis approach.
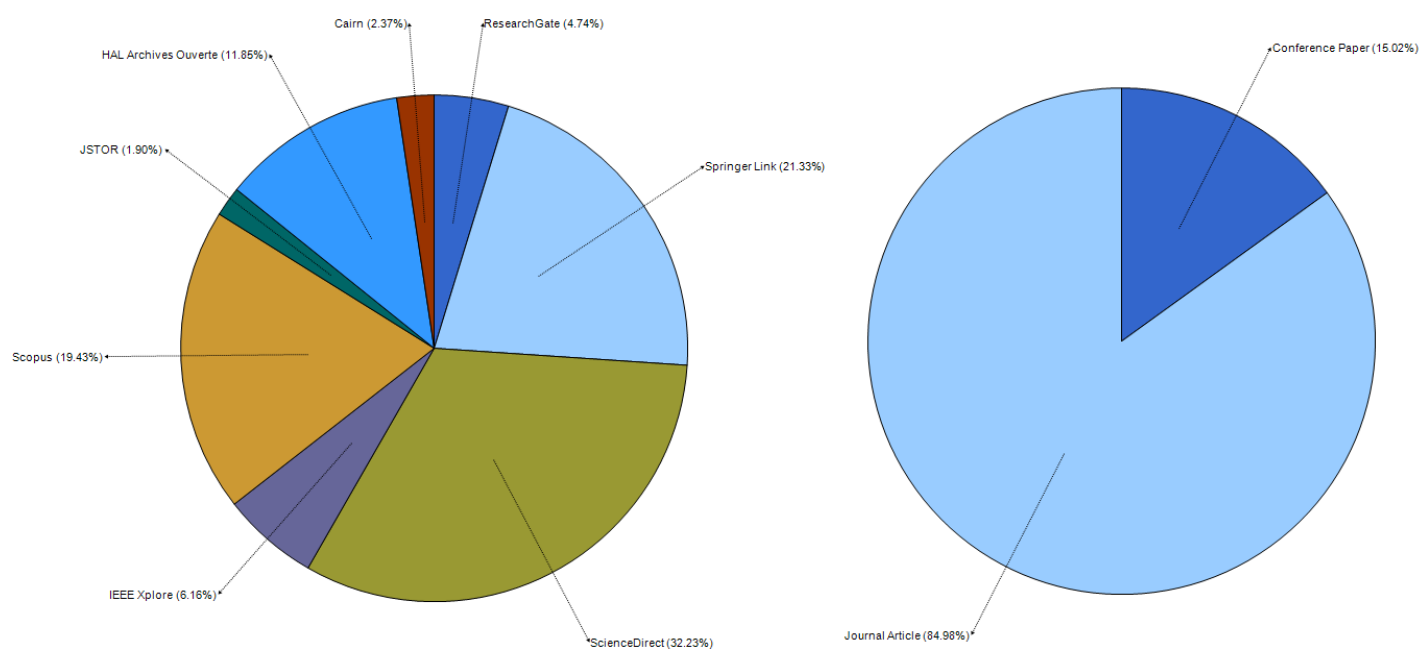

Figure 4. Illustration of distribution of sources and reference type.

\subsection{Frequency Analysis of Keywords}

The analysis of our corpus shows that the frequency of the keywords can yield some interesting insights as shown in the figure 6, we outline the learning keyword along with the game, gamification, serious, students, teaching, computer and motivation. These words represent the gamification purposes in learning, teaching and educating. 


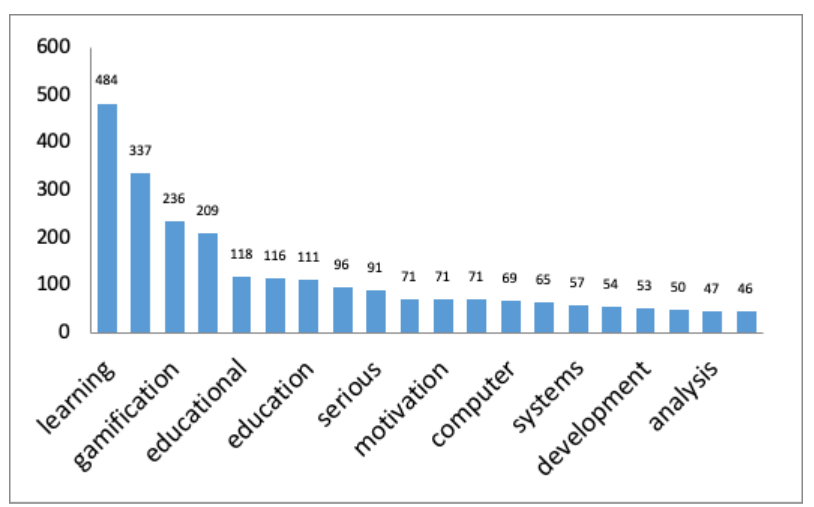

Figure 5. The histogram of the 20 most frequent words.

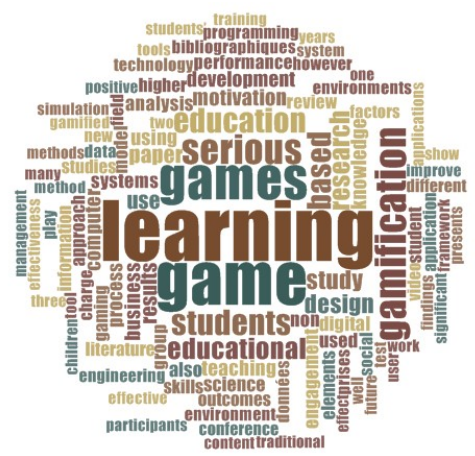

Figure 6. Keywords frequency analysis.

\section{Comparative analysis}

This section shows how each topic has been used in every research paper to present a comparative analysis that summarizes and explains the domains of gamification and online learning applications in the education field.

\subsection{Education}

The topic "Education" was mentioned more than 50 times by the authors, Borna Keivan and Hesam Maghami Rad [11] to motivate teaching in the educational environment with game-based learning, based on entertainment, challenge and engagement. They used serious educational games to compare education outcomes on selected students to experience the effects of gamification on their learning. As a result of 20 volunteers playing the game, giving their feedback, and answering the survey questions, they ended up with positive and interesting results, proving that gamification and serious games improved the student's learning efficiency and allowed complete control to monitor student's learning. On the other side, Hung-Ho Su has also brought up the topic of "Education" and "games" to prove the significant impacts of gamification in education on motivation, performance, and cognitive load [12]. Using a Gamification Software Engineering Education Learning System [12], his research's results show that education is influenced positively by gamification, besides the proven impact on student learning motivation.

To provide more proves of the benefits of using gamification in education, the research of Victoria Guillén-Nieto used a serious game called "It's a deal" [13] to reveal the efficiency and effectiveness of a game-play in business 
English teaching. One hundred six students passed a pre-test then played the game. After that, they gave a post-test, compared the results to conclude a significant finding: games have undeniable educational potential.

Table 1. The list of research papers set of reviews referring the most to "Education" topic.

\begin{tabular}{|c|c|c|c|c|}
\hline & Article Type & $\begin{array}{l}\text { Methodology } \\
\text { Approach }\end{array}$ & Definition & Characteristics \\
\hline $\begin{array}{l}\text { Wassila, } \\
\text { Debabi; } \\
\text { Tahar, } \\
\text { Bensebaa } \\
(2012)\end{array}$ & Review & Qualitative & $\begin{array}{l}\text { The authors of this paper define } \\
\text { serious games as "a mental con- } \\
\text { test, played with a computer fol- } \\
\text { lowing specific rules that use } \\
\text { entertainment to further govern- } \\
\text { ment or corporate training, edu- } \\
\text { cation, health, public policy, and } \\
\text { strategic communication objec- } \\
\text { tives" [14]. According to them, the } \\
\text { most important purpose of serious } \\
\text { games is the relationship between } \\
\text { the game and the educational con- } \\
\text { tent [14] }\end{array}$ & $\begin{array}{lr}\text { Attraction, } & \text { Fun, Simula- } \\
\text { tion, Encouragement of } \\
\text { player, } & \text { Edutainment, } \\
\text { Mastering r contents, } \\
\text { Develop r attitudes, } \\
\text { Communicate r and } \\
\text { cooperate, Make decisions }\end{array}$ \\
\hline $\begin{array}{l}\text { Seng, Wong } \\
\text { Yoke; Yatim, } \\
\text { Maizatul } \\
\text { Hayati } \\
\text { Mohamad } \\
\text { (2014) }\end{array}$ & Review & $\begin{array}{l}\text { Systematic Liter- } \\
\text { ature Review / } \\
\text { Qualitative }\end{array}$ & $\begin{array}{l}\text { Based on the definition given by } \\
\text { the authors of this review, com- } \\
\text { puter games are a tool of teach- } \\
\text { ing and efficient learning than the } \\
\text { standard approaches in raising stu- } \\
\text { dents' skills and knowledge and } \\
\text { engaging them in a challenging } \\
\text { manner. }\end{array}$ & $\begin{array}{l}\text { Interaction, Communica- } \\
\text { tion, Feedback, Reaction, } \\
\text { User friendly interface, } \\
\text { Animation, Reward system }\end{array}$ \\
\hline $\begin{array}{l}\text { Paralič, M.; } \\
\text { Pietriková, E. } \\
\text { (2014) }\end{array}$ & Review & Qualitative & $\begin{array}{l}\text { As stated by the authors, the } \\
\text { games used as teaching concept to } \\
\text { increase motivation and gain a lot } \\
\text { of benefits in education [15]. }\end{array}$ & $\begin{array}{l}\text { Program logic , Design, } \\
\text { Input, Output }\end{array}$ \\
\hline $\begin{array}{l}\text { Subhash, } \\
\text { Sujit; Cuney, } \\
\text { Elizabeth A. } \\
\text { (2018) }\end{array}$ & Review & $\begin{array}{l}\text { Systematic Liter- } \\
\text { ature Review / } \\
\text { Qualitative }\end{array}$ & $\begin{array}{l}\text { Gamification is defined by "the } \\
\text { use of game design elements } \\
\text { in non-game contexts" [16], and } \\
\text { the primary purpose is to boost } \\
\text { engagement and motivation. }\end{array}$ & $\begin{array}{l}\text { Badges, Collaboration, } \\
\text { Graphics, Leaderboard, } \\
\text { Real rewards, Roleplay, } \\
\text { Feedback, Freedom to fail }\end{array}$ \\
\hline $\begin{array}{l}\text { Ariffin, } \\
\text { Mazeyanti } \\
\text { Mohd; } \\
\text { Oxley, Alan; } \\
\text { Sulaiman, } \\
\text { Suziah } \\
(2014)\end{array}$ & Review & $\begin{array}{l}\text { Literature } \\
\text { Review } \\
\text { Qualitative }\end{array}$ & $\begin{array}{l}\text { The authors of this research paper } \\
\text { refer to game-based learning as } \\
\text { the use of computer games having } \\
\text { educational value or any software } \\
\text { applications using games for learn- } \\
\text { ing and education purposes [17] }\end{array}$ & Not specified \\
\hline
\end{tabular}

In the Table. 1, we selected the list of research papers set of reviews referring the most to the "education" topic, we analyzed each one to retrieve the approach followed by the authors. We summarized the definition of education using games relatively to these researches. Finally, we extracted the characteristics a game should have to teach and learn effectively. The interpretations we made of these research papers act as a stepping stone to dig deeper into the use of games in education. In the next step, we examined a list of research papers set of results, our analysis detailed in the Table. 2 the study's context of each document, the method and the experiment achieved and the final fruit of these experiences. 
Table 2. The list of research papers set of results referring the most to the "Education" topic.

\begin{tabular}{|c|c|c|c|c|c|}
\hline & $\begin{array}{l}\text { Article } \\
\text { Type }\end{array}$ & $\begin{array}{l}\text { Methodology/ } \\
\text { Approach }\end{array}$ & Context & Method/ Sample & Results \\
\hline $\begin{array}{l}\text { Hwang, } \\
\text { Gwo-Jen; } \\
\text { Sung, Han- } \\
\text { Yu; Hung, } \\
\text { Chun-Ming; } \\
\text { Huang, } \\
\text { Iwen; Tsai, } \\
\text { Chin- Chung } \\
\text { (2012) }\end{array}$ & Result & Experience & $\begin{array}{l}\text { This study aims to propose a } \\
\text { game-based learning approach } \\
\text { based on different learning } \\
\text { styles then experiment with } \\
\text { it to check the efficiency of } \\
\text { their personalized educational } \\
\text { game. }\end{array}$ & $\begin{array}{l}\text { Implementing a role-playing game on } \\
\text { a natural science course about: "an } \\
\text { ancient kingdom in which the people } \\
\text { are infected by poisoned water in a } \\
\text { river.The students play the role of a } \\
\text { king to find the target plants; they are } \\
\text { required to pass several tests during } \\
\text { their journeys." [18] }\end{array}$ & $\begin{array}{l}\text {-Promotes motivation } \\
\text {-Improves achievements } \\
\text {-Increase performance }\end{array}$ \\
\hline $\begin{array}{l}\text { Su, Chung- } \\
\text { Ho (2016) }\end{array}$ & Result & Experience & $\begin{array}{l}\text { This study carries out the } \\
\text { development of a Gamification } \\
\text { Software Engineering Educa- } \\
\text { tion Learning System to mea- } \\
\text { sure the evolution of learning } \\
\text { motivation and cognitive load. }\end{array}$ & $\begin{array}{l}\text { Through the development of Gamifi- } \\
\text { cation Software Engineering Educa- } \\
\text { tion Learning System using a gamified } \\
\text { learning strategy, they had } 107 \text { ques- } \\
\text { tionnaires ready to be analyzed. }\end{array}$ & $\begin{array}{l}\text { The findings of this research } \\
\text { were interesting, gamification } \\
\text { has a: - positive effect on learn- } \\
\text { ing motivation - positive effect } \\
\text { on academic performance - } \\
\text { negative effect on learning anx- } \\
\text { iety - negative effect with cog- } \\
\text { nitive load }\end{array}$ \\
\hline $\begin{array}{l}\text { Guillén- } \\
\text { Nieto, Victo- } \\
\text { ria; Aleson- } \\
\text { Carbonell, } \\
\text { Marian } \\
(2012)\end{array}$ & Result & Simulation & $\begin{array}{l}\text { This research paper studies } \\
\text { the influence of serious games } \\
\text { in intercultural communicative } \\
\text { and interactive learning envi- } \\
\text { ronments. }\end{array}$ & $\begin{array}{l}\text { One hundred six students in English } \\
\text { Studies at the University of Alicante } \\
\text { played It's a Deal!, game providing } \\
\text { the challenge of making a deal with } \\
\text { some significant toy distributor to let } \\
\text { the players see different stages: sales } \\
\text { operation, making contact, quotation, } \\
\text { order, delivery and payment. }\end{array}$ & $\begin{array}{l}\text { After achieving the pre-test and } \\
\text { the post-test questionnaires by } \\
\text { all the students, found that } \\
\text { video game is an effective } \\
\text { tool for learning and teaching } \\
\text { obtained by the results of } \\
\text { performed tests. }\end{array}$ \\
\hline $\begin{array}{l}\text { Khan, Amna; } \\
\text { Ahmad, } \\
\text { Farzana } \\
\text { Hayat; Malik, } \\
\text { Muhammad } \\
\text { Muddassir } \\
(2017)\end{array}$ & Result & Experience & $\begin{array}{l}\text { This research focuses on study- } \\
\text { ing student's engagement in } \\
\text { science classrooms based on } \\
\text { game-based learning in sec- } \\
\text { ondary school. }\end{array}$ & $\begin{array}{l}\text { A sample of } 72 \text { 8th-grade students } \\
\text { used the application designed and } \\
\text { implemented based on these game ele- } \\
\text { ments: feedback, points, visuals, chal- } \\
\text { lenge, background music, interactiv- } \\
\text { ity, goals, progression, and levels.[19] }\end{array}$ & $\begin{array}{l}\text { To evaluate the learning ben- } \\
\text { efits and outcomes before and } \\
\text { after the experience, pre and } \\
\text { post-tests were accomplished } \\
\text { to find out that: } 95 \% \text { of stu- } \\
\text { dents has a better understand- } \\
\text { ing in learning Science con- } \\
\text { cepts and exponential increase } \\
\text { of student's engagement. }\end{array}$ \\
\hline $\begin{array}{l}\text { Ibarra- } \\
\text { Herrera, } \\
\text { Celeste C.; } \\
\text { Carrizosa, } \\
\text { Alejandro; } \\
\text { Yunes-Ro- } \\
\text { jas, Julián } \\
\text { A.; Mata- } \\
\text { Gómez, } \\
\text { Marco A. } \\
(2019) \quad\end{array}$ & Result & $\begin{array}{l}\text { Simulation } \\
\& \text { survey / } \\
\text { Experimental }\end{array}$ & $\begin{array}{l}\text { This study tests an interac- } \\
\text { tive approach on groups of } \\
12 \text { students from the engineer- } \\
\text { ing school of Tecnologico de } \\
\text { Monterrey to encourage engi- } \\
\text { neering students of the biology } \\
\text { field, increase their motivation } \\
\text { and interest to learn the biology } \\
\text { topics. }\end{array}$ & $\begin{array}{l}\text { Using an application entitled 'Bio3D' } \\
\text { constituted with game elements and } \\
\text { storytelling to discover the central } \\
\text { dogma of biology ", a series of pro- } \\
\text { cesses that cells use when replicating } \\
\text { and when fabricating proteins" [20] }\end{array}$ & $\begin{array}{l}\text { After using the app, the tests } \\
\text { to evaluate the learning expe- } \\
\text { rience show that students : } \\
\text { - felt so motivated regarding } \\
\text { the gamification elements of } \\
\text { the app and the storytelling - } \\
\text { improved regarding the knowl- } \\
\text { edge evaluation }\end{array}$ \\
\hline $\begin{array}{l}\text { Jafari, Seyed } \\
\text { Moham- } \\
\text { madbagher; } \\
\text { Abdollah- } \\
\text { zade, Zahra } \\
\text { (2019) }\end{array}$ & Result & $\begin{array}{l}\text { Survey / } \\
\text { Quantitative }\end{array}$ & $\begin{array}{l}\text { To figure out the Felder- } \\
\text { Silverman learning styles } \\
\text { model (FSLSM) relationship } \\
\text { with some types of games } \\
\text { (puzzle, casual, simulation } \\
\text { games) mainly to help } \\
\text { designing games more } \\
\text { efficiently in educational } \\
\text { environments. }\end{array}$ & $\begin{array}{l}\text { By collecting data from } 121 \text { students } \\
\text { of universities from different fields } \\
\text { chosen randomly, the authors ana- } \\
\text { lyzed only } 92 \text { questionnaires, and the } \\
\text { rest was left out because of unreliable } \\
\text { answers. }\end{array}$ & $\begin{array}{l}\text { According to their findings: } \\
\text { there is an affirmative relation- } \\
\text { ship between sequential learn- } \\
\text { ing style and puzzle games. }\end{array}$ \\
\hline $\begin{array}{l}\text { Perini, } \\
\text { Stefano; } \\
\text { Luglietti, } \\
\text { Rossella; } \\
\text { Margoudi, } \\
\text { Maria; } \\
\text { Oliveira, } \\
\text { Manuel; } \\
\text { Taisch, } \\
\text { Marco (2018) }\end{array}$ & Result & $\begin{array}{l}\text { Experience } \\
\& \text { Survey / } \\
\text { Experimental }\end{array}$ & $\begin{array}{l}\text { The research discusses the } \\
\text { application of gamification in } \\
\text { manufacturing and industrial } \\
\text { areas for education and train- } \\
\text { ing. }\end{array}$ & $\begin{array}{l}\text { Based upon a game called "Life } \\
\text { Cycle Assessment" developed on co- } \\
\text { design process in two years and } \\
\text { involving } 265 \text { university students as } \\
\text { users, the authors show the effective } \\
\text { use of digital games in universities } \\
\text { and companies. }\end{array}$ & $\begin{array}{l}\text { The LCA game is released } \\
\text { after multiple versions using } \\
\text { pre and post-test based on } \\
\text { questionnaires to elaborate } \\
\text { their results finally: High } \\
\text { scalability, Focus, Implication, } \\
\text { Relevant contribution, } \\
\text { Engagement and Evolution of } \\
\text { soft skills. }\end{array}$ \\
\hline
\end{tabular}




\subsection{Gamification}

According to Alsawaier [21], in his literature review on gamification, motivation and engagement, mentioned twenty-four occurrences of the "Gamification" them. Game-based learning and gamification are unlike as the two concepts are distinct. The main difference between the two is the incorporation of game features and elements in the training environment. The research convoy the relationship between gamification and human psychology, especially behavioural science. Multiple researchers confirmed this connection: John B. Watson (1878-1958) [22], refused introspective methods and sought to restrict psychology to experimental methods and B.F. Skinner (19041990) [23], who conducted a research on operant conditioning.

Driven by the emergence of video games amongst students and becoming part of their cultures, such as movies or books, the research of Wassila sought the use of serious games to apply gamification to the learning sector by simplifying the learning algorithm.

Table 3. The list of research papers set of reviews referring the most to "Gamification" topic.

\begin{tabular}{|c|c|c|c|c|}
\hline & $\begin{array}{l}\text { Article } \\
\text { Type }\end{array}$ & $\begin{array}{l}\text { Methodology } \\
\text { Approach }\end{array}$ & Definition & Characteristics \\
\hline $\begin{array}{l}\text { Alsawaier, } \\
\text { Raed (2017) }\end{array}$ & Review & $\begin{array}{l}\text { Literature } \\
\text { review / } \\
\text { Qualitative }\end{array}$ & $\begin{array}{l}\text { The gamification, according to the } \\
\text { authors of this research paper, is } \\
\text { the application of game elements } \\
\text { in pedagogical contexts to flourish } \\
\text { the motivation and engagement in } \\
\text { learning }\end{array}$ & $\begin{array}{l}\text {-Avatars } \\
\text { - Quests and challenges } \\
\text { - Badges } \\
\text {-Points and levels }\end{array}$ \\
\hline $\begin{array}{l}\text { Ravyse, } \\
\text { Werner } \\
\text { Siegfried; } \\
\text { Seugnet } \\
\text { Blignaut, A.; } \\
\text { Leendertz, } \\
\text { Verona; } \\
\text { Woolner, } \\
\text { Alex (2017) }\end{array}$ & Review & $\begin{array}{l}\text { Systematic } \\
\text { review } \\
\text { Qualitative }\end{array}$ & $\begin{array}{l}\text { This study focuses on the factors } \\
\text { which made a successful serious } \\
\text { game. The authors define serious } \\
\text { games relatively to their applica- } \\
\text { tion. Still, they state that serious } \\
\text { games have an educational pur- } \\
\text { pose additionally to entrainment. }\end{array}$ & $\begin{array}{l}\text {-Backstory and production } \\
\text { - Realism } \\
\text {-AI and adaptivity } \\
\text {-Interaction } \\
\text {-Feedback and debriefing }\end{array}$ \\
\hline $\begin{array}{l}\text { Alhammad, } \\
\text { Manal M.; } \\
\text { Moreno, Ana } \\
\text { M. (2018) }\end{array}$ & Review & $\begin{array}{l}\text { Systematic } \\
\text { review } \\
\text { Qualitative }\end{array}$ & $\begin{array}{l}\text { As said by the researchers of this } \\
\text { study, gamification is a powerful } \\
\text { method in different applications } \\
\text { influencing human behaviour }\end{array}$ & $\begin{array}{l}\text { - Dynamics: } \\
\text { Narrative, Emotions, Progression } \\
\text { - Mechanics : } \\
\text { Cooperation, Competition, } \\
\text { Challenge, Feedback, Rewards } \\
\text { - Components : } \\
\text { Badges, Points, Levels, } \\
\text { Leaderboards, Achievements, } \\
\text { Quests, Teams }\end{array}$ \\
\hline
\end{tabular}

We did the same analysis described previously on the review and result papers related to the gamification topic, Table. 3 and Table. 4 presents the definition's attribute, characteristics and describes the evaluated experiments used with their results, respectively. 
Table 4. The list of research papers set of results referring the most to the "Gamification" topic.

\begin{tabular}{|c|c|c|c|c|c|}
\hline & $\begin{array}{l}\text { Article } \\
\text { Type }\end{array}$ & $\begin{array}{l}\text { Methodology } \\
\text { Approach }\end{array}$ & Context & Method/ Sample & Results \\
\hline $\begin{array}{l}\text { Kim, Jung } \\
\text { Tae; Lee, } \\
\text { Won-Hyung } \\
\text { (2015) }\end{array}$ & Result & $\begin{array}{l}\text { Modeling / } \\
\text { Qualitative }\end{array}$ & $\begin{array}{l}\text { This study aims to extend } \\
\text { the educational effective- } \\
\text { ness by proposing a dynam- } \\
\text { ical model for gamification } \\
\text { of learning. }\end{array}$ & $\begin{array}{l}\text { By analyzing and correlat- } \\
\text { ing four main factors built } \\
\text { on multiple theories: } \\
\text { 1- Game Design Features } \\
\text { 2- Key Characteristics of a } \\
\text { Learning Game } \\
\text { 3- Theory of the ARCS } \\
\text { (attention, relevance, confi- } \\
\text { dence, and satisfaction) } \\
\text { 4- The MDA(mechanics, } \\
\text { dynamics and aesthetics) } \\
\text { framework }\end{array}$ & $\begin{array}{l}\text { - Curiosity: } \\
\text { Envy, Connection ... } \\
\text { - Challenge: } \\
\text { Goal,Quest, Levels, Points } \\
\text {... } \\
\text { - Fantasy: } \\
\text { Virtual items, Feedback, } \\
\text { Delight ... } \\
\text { - Control }\end{array}$ \\
\hline $\begin{array}{l}\text { Ofosu- } \\
\text { Ampong, } \\
\text { Kingsley; } \\
\text { Boateng, } \\
\text { Richard; } \\
\text { Anning-Dor- } \\
\text { son, Thomas; } \\
\text { Kolog, } \\
\text { Emmanuel } \\
\text { A. (2019) }\end{array}$ & Result & $\begin{array}{l}\text { Exploratory } \\
\text { Analysis / } \\
\text { Quantitative }\end{array}$ & $\begin{array}{l}\text { This research accepted } \\
\text { gamification as known } \\
\text { for its significant effect in } \\
\text { teaching and learning in } \\
\text { higher education. }\end{array}$ & $\begin{array}{l}\text { Using the existing accep- } \\
\text { tance models and extending } \\
\text { some of them, the authors } \\
\text { tested the student's per- } \\
\text { ception and acceptance in } \\
\text { higher education, including } \\
\text { graduate and undergraduate } \\
\text { participants of the Univer- } \\
\text { sity of Ghana [24] }\end{array}$ & $\begin{array}{l}\text { The results elaborated by } \\
\text { the questionnaires showed } \\
\text { that student's behavioural } \\
\text { intent to use gamification to } \\
\text { learn is: } \\
\text { - Positively related to per- } \\
\text { formance expectancy, effort } \\
\text { expectancy, attitude, facil- } \\
\text { itating conditions, social } \\
\text { influence and trust } \\
\text { - Negatively affected by } \\
\text { image. }\end{array}$ \\
\hline $\begin{array}{l}\text { Kazimoglu, } \\
\text { Cagin; } \\
\text { Kiernan, } \\
\text { Mary; } \\
\text { Bacon, Liz; } \\
\text { Mackinnon, } \\
\text { Lachlan } \\
\text { (2012) }\end{array}$ & Result & $\begin{array}{l}\text { Simulation / } \\
\text { survey }\end{array}$ & $\begin{array}{l}\text { This study concentrated } \\
\text { on Computational } \\
\text { Thinking skills to design } \\
\text { an educational game } \\
\text { framework and developed } \\
\text { it to ease learning and at- } \\
\text { tract students to learn using } \\
\text { computer video games. }\end{array}$ & $\begin{array}{l}\text { Twenty-five students } \\
\text { played the game "Program } \\
\text { your robot" created by the } \\
\text { authors to assist a robot and } \\
\text { help him escape using an } \\
\text { escape plan conceived by } \\
\text { the player himself, and then } \\
\text { he gave the commands to } \\
\text { be performed by the robot. }\end{array}$ & $\begin{array}{l}\text { The survey revealed that all } \\
\text { the students: } \\
\text { - Enjoyed while playing } \\
\text { - Enhanced their problem- } \\
\text { solving abilities }\end{array}$ \\
\hline $\begin{array}{l}\text { Urh, Marko; } \\
\text { Vukovic, } \\
\text { Goran; Jereb, } \\
\text { Eva; Pintar, } \\
\text { Rok (2015) }\end{array}$ & Result & Experience & $\begin{array}{l}\text { This research conveys } \\
\text { a model to introduce } \\
\text { gamification in e-learning } \\
\text { based on game mechanics, } \\
\text { dynamics, important } \\
\text { factors of e-learning } \\
\text { (Pedagogy, Technology, } \\
\text { Design, People), elements } \\
\text { of user experience. }\end{array}$ & $\begin{array}{l}\text { The authors developed an } \\
\text { e-learning environment }\end{array}$ & $\begin{array}{l}\text { - Higher satisfaction } \\
\text { - Motivation } \\
\text { - Greater engagement }\end{array}$ \\
\hline
\end{tabular}

\subsection{E-Learning}

Regarding the "e-Learning" topic, the usage of game elements and mechanics in e-Learning systems was driven by the primary purpose of increasing user's engagement, experience and motivation [25], Kapp described gamification in learning as the usage of game elements and features to engage the participants, motivate them, move up learning, and their solving problems [26].

But besides all of these potential benefits of gamified e-Learning systems, our focus must also be on how to use the game development tools to deliver suitable educational games in e-learning environments [27]. 
Table 5. The list of research papers set of reviews referring the most to the "e-Learning" topic.

\begin{tabular}{|c|c|c|c|c|}
\hline & $\begin{array}{l}\text { Article } \\
\text { Type }\end{array}$ & $\begin{array}{l}\text { Methodology } \\
\text { Approach }\end{array}$ & Definition & Characteristics \\
\hline $\begin{array}{l}\text { Strmečki, } \\
\text { Daniel; } \\
\text { Bernik, } \\
\text { Andrija; } \\
\text { Radosevic, } \\
\text { Danijel } \\
(2015)\end{array}$ & Review & $\begin{array}{l}\text { Comparison / } \\
\text { Qualitative }\end{array}$ & $\begin{array}{l}\text { Describing gamification as a buz- } \\
\text { zword, Daniel Strmecki initially } \\
\text { explains that gamification uses } \\
\text { game thinking, game elements and } \\
\text { game design in non-game con- } \\
\text { text, then introduces a conceptual } \\
\text { design of a gamified e-learning } \\
\text { system based on five phases: Anal- } \\
\text { ysis, design, development, imple- } \\
\text { mentation and evaluation. The } \\
\text { authors states that there is a gam- } \\
\text { ified design elements suitable for } \\
\text { e-learning systems. }\end{array}$ & $\begin{array}{l}\text { - Points } \\
\text { - rewards } \\
\text { - leaderboard } \\
\text { - Levels } \\
\text { - Challenges } \\
\text { - Social engagement loops }\end{array}$ \\
\hline $\begin{array}{l}\text { Tuparov, G.; } \\
\text { Tuparova, D. } \\
\text { (2018) }\end{array}$ & Review & $\begin{array}{l}\text { Comparison / } \\
\text { Qualitative }\end{array}$ & $\begin{array}{l}\text { In this research, a framework was } \\
\text { proposed to compare the different } \\
\text { integrators of educational games in } \\
\text { e-learning. They structured them } \\
\text { in three categories: System inte- } \\
\text { grated, System's specific exten- } \\
\text { sions, Standard-based extensions. }\end{array}$ & $\begin{array}{l}\text { They compared the functionalities } \\
\text { and plugins of the different } \\
\text { systems based on the chosen } \\
\text { characteristics : } \\
\text { - Badges } \\
\text { - Ranking } \\
\text { - Levels } \\
\text { - Student Log }\end{array}$ \\
\hline $\begin{array}{l}\text { Hung, Hsiu- } \\
\text { Ting; Yang, } \\
\text { Jie Chi; } \\
\text { Hwang, } \\
\text { Gwo-Jen; } \\
\text { Chu, Hui- } \\
\text { Chun; Wang, } \\
\text { Chun-Chieh } \\
\text { (2018) }\end{array}$ & Review & $\begin{array}{l}\text { Literature } \\
\text { Review } \\
\text { Qualitative }\end{array}$ & $\begin{array}{l}\text { Based on the author's definition, } \\
\text { a learning game is defined as "a } \\
\text { playful activity that is structured } \\
\text { by rules for the pursuit of quantifi- } \\
\text { able outcomes (e.g., win states and } \\
\text { points), and incorporates educa- } \\
\text { tional objectives (e.g., knowledge } \\
\text { acquisition) as its own end" [28] }\end{array}$ & Not specified \\
\hline
\end{tabular}


Table 6. The list of research papers set of results referring the most to the "e-Learning" topic.

\begin{tabular}{|c|c|c|c|c|c|}
\hline & Article Type & $\begin{array}{l}\text { Methodology } \\
\text { Approach }\end{array}$ & Context & Method/ Sample & Results \\
\hline $\begin{array}{l}\text { Urh, Marko; } \\
\text { Vukovic, } \\
\text { Goran; Jereb, } \\
\text { Eva; Pintar, } \\
\text { Rok (2015) }\end{array}$ & Result & $\begin{array}{l}\text { Simulation / } \\
\text { Survey }\end{array}$ & $\begin{array}{l}\text { This study conducts the } \\
\text { effectiveness of a seri- } \\
\text { ous game in improving } \\
\text { motivation and persua- } \\
\text { sion for learners. }\end{array}$ & $\begin{array}{l}\text { Using a serious game about } \\
\text { sorting boxes in the solar } \\
\text { system as a space robot } \\
\text { and testing it on volunteers } \\
\text { then getting their feedback } \\
\text { through a survey. }\end{array}$ & $\begin{array}{l}\text { Based on the survey results: - } 45 \% \\
\text { of the volunteers finds GBL more } \\
\text { effective in learning.- } 60 \% \text { agreed } \\
\text { that GBL is faster in learning than } \\
\text { usual, and } 65 \% \text { thinks it is a better } \\
\text { method. - } 85 \% \text { agreed that GBL } \\
\text { has been so beneficial for them in } \\
\text { their learning possess. }\end{array}$ \\
\hline $\begin{array}{l}\text { Cózar- } \\
\text { Gutiérrez, } \\
\text { Ramón; } \\
\text { Sáez-López, } \\
\text { José Manuel } \\
\text { (2016) }\end{array}$ & Result & $\begin{array}{l}\text { Survey / } \\
\text { Quantitative }\end{array}$ & $\begin{array}{l}\text { This study analyses } \\
\text { game-based learning } \\
\text { and gamification on } \\
\text { second-year university } \\
\text { students to learn about } \\
\text { Social Sciences II } \\
\text { aiming for a degree in } \\
\text { Primary Education. }\end{array}$ & $\begin{array}{l}\text { Through the exploration of } \\
\text { MinecraftEdu, this research } \\
\text { experiment the possibilities } \\
\text { of learning environments } \\
\text { using video games. }\end{array}$ & $\begin{array}{l}\text { The results of this experience } \\
\text { concluded that gamification in } \\
\text { the educational context boost the } \\
: \text { - Creativity - Collaboration - } \\
\text { Communication - Competences - } \\
\text { Innovation - Motivation }\end{array}$ \\
\hline $\begin{array}{l}\text { Hernández- } \\
\text { Lara, Ana } \\
\text { Beatriz; } \\
\text { Serradell- } \\
\text { López, Enric; } \\
\text { Fitó-Ber- } \\
\text { tran, Àngels } \\
(2019)\end{array}$ & Result & $\begin{array}{l}\text { Questionnaire } \\
\text { / Quantitative }\end{array}$ & $\begin{array}{l}\text { This study aims to scru- } \\
\text { tinize the learning bene- } \\
\text { fits using the e-learning } \\
\text { method based on busi- } \\
\text { ness simulation games. }\end{array}$ & $\begin{array}{l}\text { A sample of } 182 \text { students } \\
\text { of bachelor's and master's } \\
\text { degrees were involved in } \\
\text { business simulation games } \\
\text { within an official manage- } \\
\text { ment course. }\end{array}$ & $\begin{array}{l}\text { One hundred fifteen players } \\
\text { completed the questionnaire } \\
\text { to find out:- Remarkable } \\
\text { improvement of generic } \\
\text { competencies like (information } \\
\text { processing, decision-making, } \\
\text { teamwork, dealing } \\
\text { uncertainty with } \\
\text { agreements } \text { and } \\
\text { learning outcomes. }\end{array}$ \\
\hline $\begin{array}{l}\text { Strmečki, } \\
\text { Daniel; } \\
\text { Bernik, } \\
\text { Andrija; } \\
\text { Radosevic, } \\
\text { Danijel } \\
(2015)\end{array}$ & Result & Experience & $\begin{array}{l}\text { This research studies } \\
\text { the application of } \\
\text { gamification in e- } \\
\text { learning systems } \\
\text { using game elements, } \\
\text { mechanics, game } \\
\text { dynamics, aesthetics, } \\
\text { and game thinking. } \\
\text { They discuss the } \\
\text { design elements used } \\
\text { in their experience } \\
\text { and details how the } \\
\text { right selected factors } \\
\text { lead to a successful } \\
\text { implementation. The } \\
\text { main goal of this study } \\
\text { is to investigate the } \\
\text { efficiency of applying } \\
\text { gamification on the } \\
\text { conventional courses }\end{array}$ & $\begin{array}{l}\text { The authors of this research } \\
\text { followed a comparison } \\
\text { approach using Moodle } \\
\text { platform. } \\
\text { They created two versions } \\
\text { of an e-learning course } \\
\text { about Computer Graphics } \\
\text { elements, one gamified } \\
\text { and the other classical } \\
\text { (non-gamified). } \\
\text { The gamified e-learning } \\
\text { course was based on } \\
\text { these game design } \\
\text { elements: customization, } \\
\text { badges, cunts, levels, } \\
\text { leaderboards, feedback } \\
\text { challenge quest, feedr. } \\
\text { freedom to fail. }\end{array}$ & $\begin{array}{l}\text { The scores and t-tests were } \\
\text { interesting and favoured } \\
\text { the groups who played the } \\
\text { experimental online course, } \\
\text { confirming their successful } \\
\text { implementation and the practical } \\
\text { impact of gamification in e- } \\
\text { learning. }\end{array}$ \\
\hline
\end{tabular}

\subsection{Motivation}

Motivation is among the main factors of integrating game's dynamics and techniques to e-learning courses and training to increase the learners' implication. Kusuma [30] in his research paper states some gamification models helping the make of new approaches to elevate the trainee's motivation.

By designing and building a gamification plugin for an e-learning platform, Adrián Domínguez made an experiment in a university course [31], therefore their findings were challenging: the audience who achieved the gamified experience got the higher motivation and the best scores among students. 
Table 7. The list of research papers set of reviews referring the most to the "Motivation" topic.

\begin{tabular}{|l|l|l|}
\hline & Article Type & Methodology / Approach \\
\hline Alsawaier, Raed (2017) & Review & A Literature review / Qualitative \\
\hline $\begin{array}{l}\text { Kusuma, Gede Putra; Wigati, Evan Kris- } \\
\text { tia; Utomo, Yesun; Putera Suryapranata, } \\
\text { Louis Khrisna (2018) }\end{array}$ & Review & Comparison / Qualitative \\
\hline Imran, Hazra (2019) & Review & A Literature review / Qualitative \\
\hline Nguyen, Duyen (2015) & Review & A Literature review / Qualitative \\
\hline
\end{tabular}

Table 8. The list of research papers set of results referring the most to the "Motivation" topic.

\begin{tabular}{|l|l|l|}
\hline & Article Type & Methodology / Approach \\
\hline $\begin{array}{l}\text { de-Marcos, Luis; Domínguez, Adrián; } \\
\text { Saenz-de-Navarrete, Joseba; Pagés, Car- } \\
\text { men (2014) }\end{array}$ & Result & Experience \\
\hline Su, Chung-Ho (2016) & Result & Experience \\
\hline $\begin{array}{l}\text { Khan, Amna; Ahmad, Farzana Hayat; } \\
\text { Malik, Muhammad Muddassir (2017) }\end{array}$ & Result & Experience \\
\hline $\begin{array}{l}\text { Chang, Ching-Yi; Kao, Chien-Huei; } \\
\text { Hwang, Gwo-Jen; Lin, Fu-Huang (2019) }\end{array}$ & Result & Experience \\
\hline
\end{tabular}

\section{Discussion}

In this section, we will present different conceptual models of gamification, and we summarize our analysis based on the previously shown studies :

The gamification, game-based learning and serious games have proven to be efficient in the educational environment and entertaining and enjoying the learning or teaching process. As well as the significant benefits and outcomes produced by learning through video games in increasing the knowledge, engagement and performance in different fields and education degrees, Debabi Wassila and Bensebaa Tahar exploited serious games to simplify algorithm learning. In contrast, Wong Yoke Seng and Maizatul Hayati focused their research on using games for object-oriented programming in higher education [32]. Gwo-Jen Hwang headed their research to create an adaptive educational game based on the different learning styles of students. Many factors related to every student and his personalized style can affect his motivation and thus his learning performance, such as his culture, ethnicity, and native language.

\subsection{Conceptual Model for Gamification of e-Learning Environments}

As a result of different design models and frameworks were elaborated to meet this need as this model was designed by Marko Urh [33] which includes various elements like pedagogical, technological, design, administration, human, financial and gamification features to introduce gamification in the field of e-learning : 


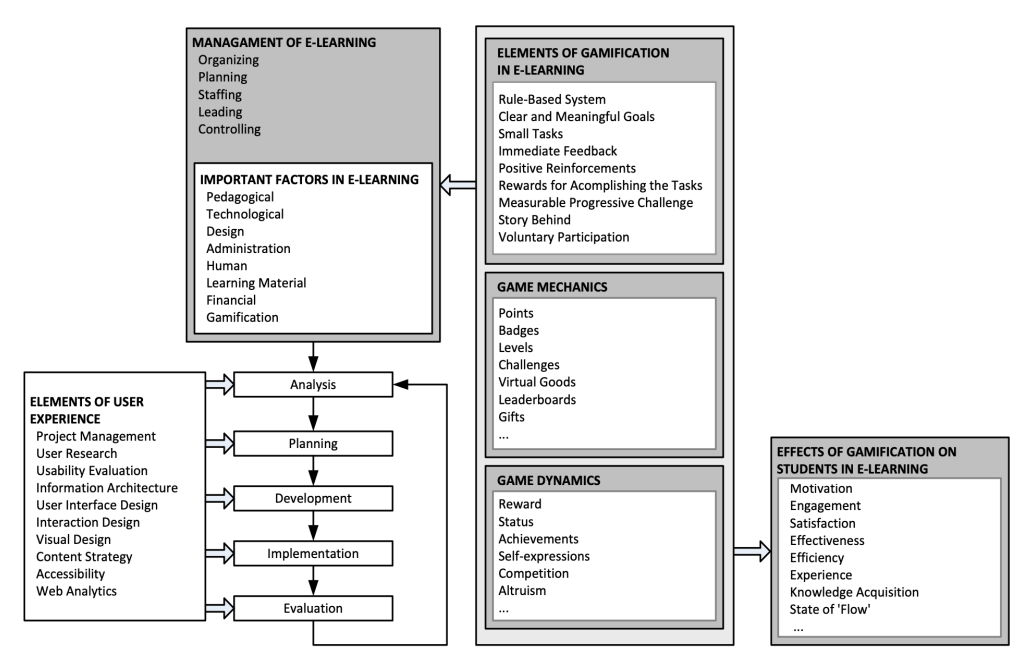

Figure 7. Model of gamification in the field of e-learning [33]

This model (Figure 7) is constituted of management of e-learning, elements of user experience, game mechanics, dynamics and a lot more essential elements, which brings us to the effects produced on students of higher education using the learning system build on this model, which are the motivation, engagement, satisfaction, efficiency, experience, knowledge acquisition and more exciting effects

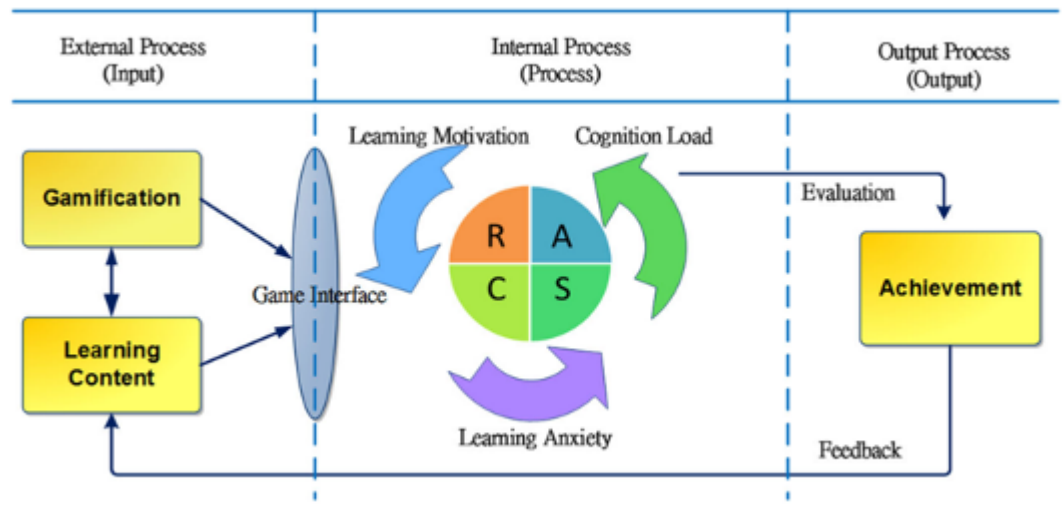

Figure 8. Model of a Software Engineering Education Learning System[31].

The second model (See Figure 8) is represented by three processes:

- External Process: the input which is the gamification learning tool.

- Internal Process: the main core based on Keller's ARCS learning model [34] based on four dimensions:

- (A)Attention: attract the intention of the player and his curiosity.

- (R) Relevance: make the player putting goals to raise his motivation and performance.

- (C) Confidence: encourage the player by rewarding him and making him believe that putting goals and achieving them is possible.

- (S) Satisfaction: learn new skills and continuously solving problems or puzzles of the game increase the feeling of success and promote his motivation.

- Output Process: the evaluation and feedback are achieved in this step for the revision of the system 


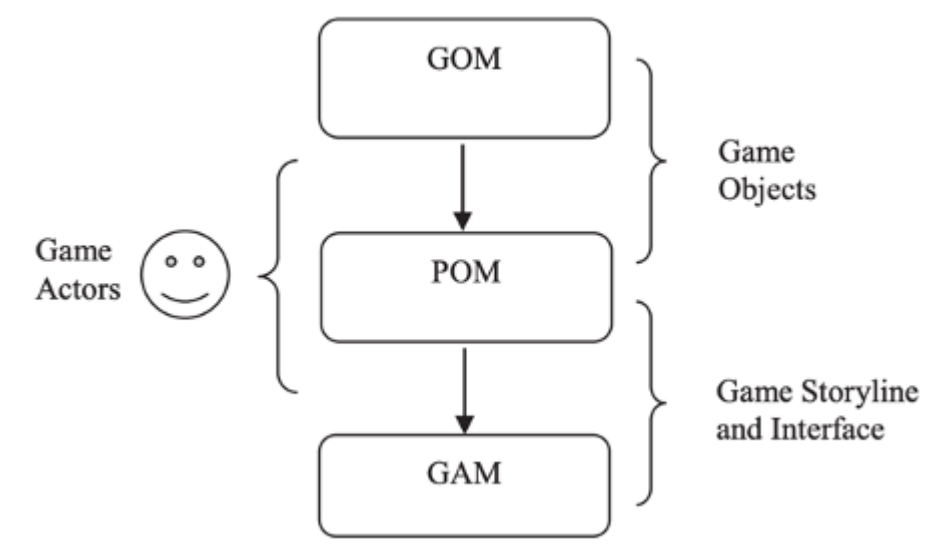

Figure 9. Model of a Software Engineering Education Learning System [32]

The third model in Figure 9 was proposed by Seng [32], is a framework including three models:

- GOM (Game Object Model): provides the learning objectives to help the design phase and development fulfilling them.

- POM (Persona Outlining Model):defines the roles and actors in the game.

- GAM (Game Achievement Model): carry the narratives and the storytelling.

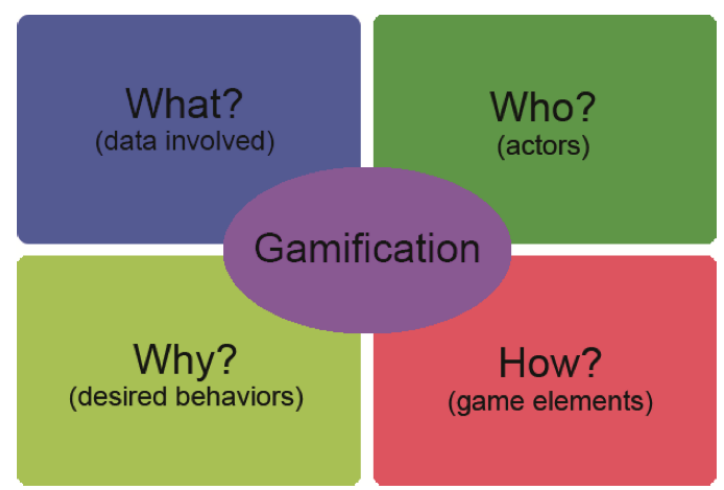

Figure 10. Model for gamification of e-learning environments [35]

The conceptual model in the Figure 10 achieved by Ana Carolina [35], and used to implement a learning environment is constituted of four dimensions :

- Who: this dimension has to identify the main actors implied in the gamification process, for example: teachers or students.

- Why: this element defines the behaviors desired by the gamified system in order to enhance the student's interaction with the process.

- What: this aspect aims to define the data, the content and the course.

- How: the how dimension serves to identify the game elements to use in the gamification process. 


\subsection{Comparative Analysis}

In the table 9, we outline the benefits and drawbacks to compare the conceptual models after analyzing them to extract the different elements composing the models and their pros and cons to summarise and conclude our first proposed framework.

Table 9. Comparative analysis of conceptual models.

\begin{tabular}{|l|l|l|}
\hline Model & Strengths & Weaknesses \\
\hline $\begin{array}{l}\text { Model of gamification in } \\
\text { the field of e-learning (Fig- } \\
\text { ure 7) }\end{array}$ & $\begin{array}{l}\text { This model includes e-learning } \\
\text { management, game elements and } \\
\text { the essential factors of pedagogy, } \\
\text { technology and design. }\end{array}$ & $\begin{array}{l}\text { The model doesn't follow a transpar- } \\
\text { adtesign the objectives and how to } \\
\text { define them with all the elements } \\
\text { declared. Also, there isn't an estab- } \\
\text { lished link between the model outputs } \\
\text { and the management step to enhance } \\
\text { the system based on the player's } \\
\text { achievements. }\end{array}$ \\
\hline $\begin{array}{l}\text { Model of a Software Engi- } \\
\text { neering Education Learning }\end{array}$ & $\begin{array}{l}\text { System (Figure 8) } \\
\text { in a loop. So, the inputs are based } \\
\text { on the evaluation and feedback } \\
\text { of results on the output process, } \\
\text { allowing the process to be agile } \\
\text { and continuously updated to define } \\
\text { the model content }\end{array}$ & $\begin{array}{l}\text { But, the learning model is limited to } \\
\text { only four axes: attention, relevance, } \\
\text { confidence and satisfaction. However, } \\
\text { aiven the effects and gains of learning } \\
\text { using a gamified system, the learning } \\
\text { model could be enriched. }\end{array}$ \\
\hline $\begin{array}{l}\text { Model of a Software Engi- } \\
\text { neering Education Learning } \\
\text { System (Figure 9) }\end{array}$ & $\begin{array}{l}\text { The model proposed a game } \\
\text { design process including the game } \\
\text { factors, objects and interface, } \\
\text { focusing on the different phases } \\
\text { to design, define, storyteller and } \\
\text { carry the game. }\end{array}$ & $\begin{array}{l}\text { Unfortunately, a framework to clarify } \\
\text { the elements of the gamified learning } \\
\text { system is not considered in this model. } \\
\text { Same for the last model (Figure 10) }\end{array}$ \\
\hline
\end{tabular}

\subsection{Proposition of theoretical model}

To propose a theoretical framework for applying gamification in e-learning environments to encourage the learners to engage with the content and progress forward.

First of all, we started by defining the inputs as they are the characteristics because what makes an environment gamified are game elements which are the features that enhance the learning experience creating a "look and feel" experience: badges, collaboration, feedback, freedom to fail, graphics leaderboard, levels, narratives, design (goals, rules, time limit, clues, competition), points, push notifications, tangible rewards, role play and competition.

Secondly, the e-learning system to gamify integrates all the characteristics mentioned in the previous paragraph and more if necessary to get an efficient application respecting gaming features. Then finally we have the outcomes and all the benefits expected as outputs of the model or design, especially :

- Motivation: according to Oxford English Dictionary motivation is "the general desire or willingness of someone to do something; drive and enthusiasm", so increasing motivation means increasing the desire to learn of the players.

- Satisfaction: defined by the fulfillment and the exciting feeling derived during and after learning using games.

- Enjoyment: defines the pleasure and the fun having along with learning by the players. 
- Engagement: refers to the learners commitment.

- Performance : means the increase of knowledge and acquisition efficiency.
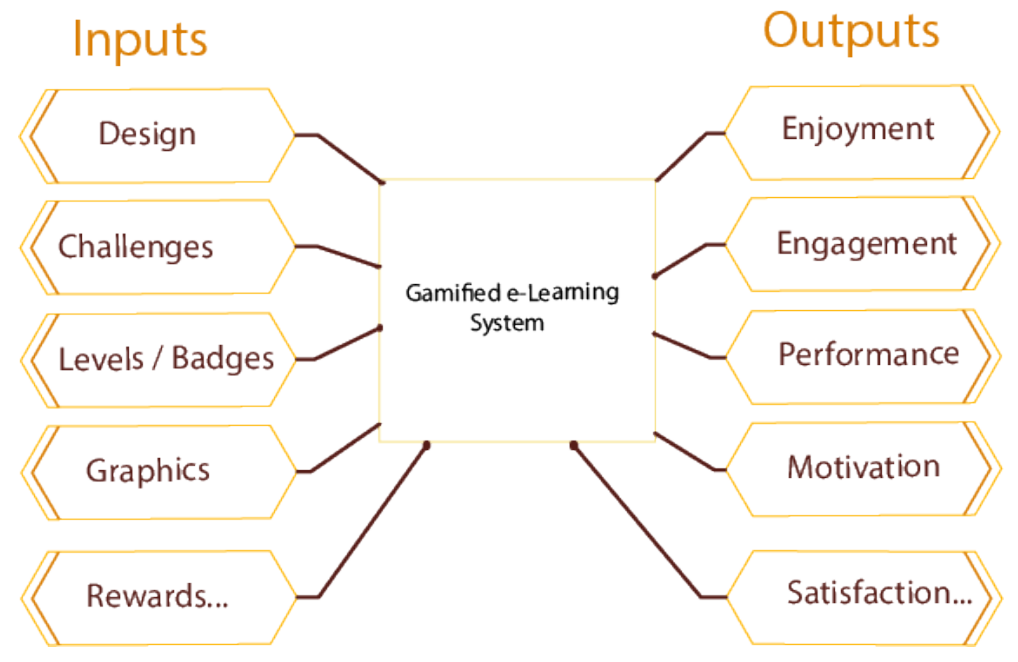

Figure 11. Gamified e-Learning system proposition model

Indeed, our proposed model didn't detail the components of our gamified e-learning system to complete the model because we are in the phase of determining the learning objectives and pedagogical design. To define these crucial elements, we started by an exploratory study using a questionnaire for laureates who freshly integrated the job sector and a qualitative method using two kinds of interviews, one for decision-makers and recruiters, the second one for ex-laureates[36].

\section{Conclusion}

As you can see through the systematic literature review conducted in this paper, apply gamification in e-learning seems to have a great potential to increase engagement, performance, efficiency, motivation and other emotional and social effects on the participants, whether students or trainees willing to experience that. Yet, it's not trivial to achieve this. Indeed, providing these opportunities required a considerable effort to be designed and implemented to create interactivity in learning delivery. Now that we have compared the existing models of games to develop our conceptual model, we will define the architecture of the gamified e-learning system so we can start implementing the prototype. The experience aims to help build the gamified educational environment to attract the audience to engage in the educational challenge to integrate enterprises and helping them to increase the productivity of the members willing to integrate companies to produce meaningful results.

\section{Perspectives}

Our study of eLearning gamification to improve professional integration will be oriented for graduated students to help them learn and build the foundation for a successful integration after graduation. The first step we started with preparing multiple interview versions for the multiple actors of our gamified system: laureates, recruiters and students. Then we will also imply the different actors in the educational and pedagogical system to prepare the courses and the gamified systems to implement and experience. Finally, let the students test the system we will build to see its impact and benefits to the laureates. The results we will conclude related the new skills they learned, primarily by increasing their motivation, enjoyment, and satisfaction to pass the course. 


\section{REFERENCES}

1. S. Zineb, M. Aniss and F. Youssef, "Gamifying eLearning to Improve Professional Integration to Labor Market Systematic Literature Review," 2020 IEEE 2nd International Conference on Electronics, Control, Optimization and Computer Science (ICECOCS), 2020, pp. 1-6, doi: 10.1109/ICECOCS50124.2020.9314372.

2. Alhammad, Manal M. y Moreno Sánchez-Capuchino, Ana María (2018). Gamification in software engineering education: a systematic mapping. "Journal of Systems and Software", v. 141 ; pp. 131-150. ISSN 0164-1212. https://doi.org/10.1016/j.jss.2018.03.065

3. Baptista, G.,\& Oliveira, T. (2019). Gamification and serious games: A literature meta-analysis and integrative model. Computers in Human Behavior,92,306-315. https://doi.org/10.1016/j.chb.2018.11.030

4. Hanes, L., Stone, R. A model of heritage content to support the design and analysis of video games for history education. J. Comput. Educ. 6, 587-612 (2019). https://doi.org/10.1007/s40692-018-0120-2

5. Zeffiro V., Di Fuccio R., Vellone E., Alvaro R., D’Agostino F. (2021) A Serious Game and Negotiation Skills in Nursing Students: A Pilot Study. In: Kubincová Z., Lancia L., Popescu E., Nakayama M., Scarano V., Gil A (eds) Methodologies and Intelligent Systems for Technology Enhanced Learning, 10th International Conference. Workshops. MIS4TEL 2020. Advances in Intelligent Systems and Computing, vol 1236.Springer, Cham. https://doi.org/10.1007/978-3-030-52287-2-9

6. Cagin Kazimoglu, Mary Kiernan, Liz Bacon, Lachlan Mackinnon,A Serious Game for Developing Computational Thinking and Learning Introductory Computer Programming, Procedia - Social and Behavioral Sciences, Volume 47,2012,Pages 1991-1999,ISSN 1877-0428,https://doi.org/10.1016/j.sbspro.2012.06.938.

7. O’Neill, M., Booth, S. (2017a). N7 + 1 Literature reviews. Retrieved from https:/ www.legworkconsultancy.com.au/ebook

8. https://en.wikipedia.org/wiki/Zotero.

9. https://en.wikipedia.org/wiki/NVivo.

10. Aniss Moumen, "Séminaire sur la méthodologie de recherche \& guide des bonnes pratiques et techniques en communication, rédaction et publication scientifique", 2018.

11. K. Borna and H. M. Rad, "Serious Games in Computer Science Learning Goals," 2018 2nd National and 1st International Digital Games Research Conference: Trends, Technologies, and Applications (DGRC), Tehran, Iran, 2018, pp. 161-166, doi: 10.1109/DGRC.2018.8712030.

12. $\mathrm{Su}, \mathrm{CH}$. The effects of students' motivation, cognitive load and learning anxiety in gamification software engineering education: a structural equation modeling study. Multimed Tools Appl 75, 10013-10036 (2016). https://doi.org/10.1007/s11042-015-2799-7

13. Victoria Guillén-Nieto, Marian Aleson-Carbonell,Serious games and learning effectiveness: The case of It's a Deal!,Computers \& Education,Volume 58, Issue 1,2012,Pages 435-448,ISSN 0360-1315,https://doi.org/10.1016/j.compedu.2011.07.015.

14. D. Wassila and B. Tahar, "Using serious game to simplify algorithm learning," International Conference on Education and e-Learning Innovations, Sousse, Tunisia, 2012, pp. 1-5, doi: 10.1109/ICEELI.2012.6360569.

15. M. Paralič and E. Pietriková, "Learning by game creation in introductory programming course: 5-Year-long study," 2014 IEEE 12 th IEEE International Conference on Emerging eLearning Technologies and Applications (ICETA), Stary Smokovec, Slovakia, 2014, pp. 391-396, doi: 10.1109/ICETA.2014.7107617.

16. Sujit Subhash, Elizabeth A. Cudney,Gamified learning in higher education: A systematic review of the literature,Computers in Human Behavior,Volume 87,2018,Pages 192-206,ISSN 0747-5632,https://doi.org/10.1016/j.chb.2018.05.028.

17. Mazeyanti Mohd Ariffin, Alan Oxley, Suziah Sulaiman,Evaluating Game-based Learning Effectiveness in Higher Education,Procedia - Social and Behavioral Sciences, Volume 123,2014,Pages 20-27,ISSN 1877-0428,https://doi.org/10.1016/j.sbspro.2014.01.1393.

18. Hwang, GJ., Sung, HY., Hung, CM. et al. Development of a personalized educational computer game based on students' learning styles. Education Tech Research Dev 60, 623-638 (2012). https://doi.org/10.1007/s11423-012-9241-x.

19. Khan, A., Ahmad, F. \& Malik, M.M. Use of digital game based learning and gamification in secondary school science: The effect on student engagement, learning and gender difference. Educ Inf Technol 22, 2767-2804 (2017). https://doi.org/10.1007/s10639-0179622-1.

20. Ibarra-Herrera, C.C., Carrizosa, A., Yunes-Rojas, J.A. et al. Design of an app based on gamification and storytelling as a tool for biology courses. Int J Interact Des Manuf 13, 1271-1282 (2019). https://doi.org/10.1007/s12008-019-00600-8.

21. Alsawaier, R.S. (2018), "The effect of gamification on motivation and engagement", International Journal of Information and Learning Technology, Vol. 35 No. 1, pp. 56-79. https://doi.org/10.1108 IJILT-02-2017-0009.

22. Watson, J. B. (1913). Psychology as the behaviorist views it. Psychological Re- view, 20, 158-177.

23. Skinner, B.F. (1974). About behaviorism. New York, NY: Random House.

24. Ofosu-Ampong, Kingsley; Boateng, Richard; Anning-Dorson, Thomas; Kolog, Em- manuel A., Are we ready for Gamification? An exploratory analysis in a developing country, 2019.

25. Andrija Bernik, Danijel Radosevic, "Gamification in E-Learning: Introducing Gamified Design Elements into E-Learning Systems",2016.

26. Kapp, K.M., 2012. The Gamification of Learning and Instruction: Game-Based Meth- ods and Strategies for Training and Education. 1st Edn., John Wiley and Sons, San Francisco, CA, ISBN-10: 1118096347, pp: 302.

27. G. Tuparov and D. Tuparova, "Approaches for integration of educational computer games in e-learning environments," $201841 \mathrm{st}$ International Convention on Information and Communication Technology, Electronics and Microelectronics (MIPRO), Opatija, 2018, pp. 0772-0776, doi: 10.23919/MIPRO.2018.8400143.

28. Hung, H.-T., Yang, J. C., Hwang, G.-J., Chu, H.-C., \& Wang, C.-C., A scoping review of research on digital game-based language learning. Computers \& Education, 2018,https://doi.org/10.1016/j.compedu.2018.07.001.

29. Hernández-Lara, A. B., Serradell-López, E., \& Fitó-Bertran, À, Students' perception of the impact of competences on learning: An analysis with business simulations. Com- puters in Human Behavior, 2019,https://doi.org/10.1016/j.chb.2019.07.023

30. Gede Putra Kusuma, Evan Kristia Wigati, Yesun Utomo, Louis Khrisna Putera Suryapranata,Analysis of Gamification Models in Education Using MDA Framework,Procedia Computer Science,Volume 135,2018,Pages 385-392,ISSN 18770509,https://doi.org/10.1016/j.procs.2018.08.187. 
31. Adrián Domínguez, Joseba Saenz-de-Navarrete, Luis de-Marcos, Luis Fernández-Sanz, Carmen Pagés, José-Javier Martínez-Herráiz, "Gamifying learning experiences: Practi- cal implications and outcomes", 2012,https://doi.org/10.1016/j.compedu.2014.01.012.

32. Wong Yoke Seng, Maizatul Hayati Mohamad Yatim,Computer Game as Learning and Teaching Tool for Object Oriented Programming in Higher Education Institution,Procedia - Social and Behavioral Sciences,Volume 123,2014,Pages 215-224,ISSN 1877-0428,https://doi.org/10.1016/j.sbspro.2014.01.1417.

33. Marko Urh, Goran Vukovic, Eva Jereb, Rok Pintar,The Model for Introduction of Gamification into E-learning in Higher Education,Procedia - Social and Behavioral Sciences,Volume 197,2015,Pages 388-397,ISSN 18770428,https://doi.org/10.1016/j.sbspro.2015.07.154.

34. Keller JM, Motivational design of instruction. In: Reigeluth CM (ed) Instructional de- sign theories and models. Lawrence Erlbaum Associates, Hillsdale, 1983.

35. T. Klock, L. F. da Cunha, M. F. de Carvalho, B. E. Rosa, A. J. Anton, and I. Gasparini, "Gamification in e-Learning Systems: A Conceptual Model to Engage Students and Its Application in an Adaptive e-Learning System," in International Conference on Learning and Collaboration Technologies, pp. 595-607, 2015, doi: 10.1007/978-3-319-20609-756.

36. Serious Games at the service of student's integration into the work sector: Case of computer science engineering students Zineb Sabri, Aniss Moumen and Youssef Fakhri SHS Web Conf., 119 (2021) 05005 DOI: https://doi.org/10.1051/shsconf/202111905005. 